\title{
Effect of Plant Population Density and Methods of Weed Control on The Yield of Pepper (Capsicum annum L.) in Northeastern Nigeria
}

\author{
1'MUSTAPHA, AB; ${ }^{1}$ FELIX, T; ${ }^{1}$ TASHIWA, MC; ${ }^{2}$ GWORGWOR, NA \\ Department of Crop Production \& Horticulture, Modibbo Adama University of Technology, Yola, Nigeria \\ ${ }^{2}$ Department of Crop Production, University of Jos, Nigeria \\ *Corresponding Author Email: abmustaph@mautech.edu.ng
}

\begin{abstract}
Field experiments were conducted at Yola and Garkida in Adamawa State, North-Eastern Nigeria during the 2017 rainy season. In the Yola location the experiment was conducted at the Teaching and Research Farm of the Department of Crop Production and Horticulture, Modibbo Adama University of Technology, Yola, and in Garkida it was conducted at Garkida village in Gombi Local Government Area of Adamawa State. The experiment was designed to study the effect of plant population density and methods of weed control on the yield of pepper (Capsicum annum L.). The treatments consist of three spacings, $25 \times 30 \mathrm{~cm}, 35 \times 40 \mathrm{~cm}$ and $45 \times 50 \mathrm{~cm}$ with four (4) different herbicides rates (No herbicide, pyrithiobac sodium $65.5 \mathrm{~kg}$ a.i/ha, pendimethalin $1 \mathrm{~kg}$ a.i $/ \mathrm{ha}+$ pyrithiobac sodium $65.5 \mathrm{~kg}$ a.i $/$ ha and Haloxyfop $108 \mathrm{~g}$ a.i/ha + hand hoe weeding. The experimental design was a split-plot design replicated three times. Spacing was assigned to the main plot while methods of weed control as subplots. Parameters measured were weed density, number of pepper fruits per plot, and fruit yield per hectare. All data were subjected to analysis of variance (ANOVA) appropriate to the split-plot design. The results of the experiment showed that herbicide pyrthiobac sodium $65.5 \mathrm{~kg}$ a.i $/ \mathrm{ha}$ recorded the highest number of fruit per plot of 72.4 while herbicide haloxyfop $108 \mathrm{~g}$ a.i/ha followed by hand weeding recorded the least number of fruits of 50.1. The result of the experiment shows that there was a significant effect on spacing in both locations. Concerning yield per hectare spacing $25 \times 30 \mathrm{~cm}$ obtained the highest yield per hectare of $945 \mathrm{~kg}$ in Garkida, while the least was from the Yola location which recorded $537 \mathrm{~kg}$. It was concluded that pepper yield depends on the proper spacing and proper use of herbicide which will suppress weed and increase yield significantly.
\end{abstract}

\section{DOI: https://dx.doi.org/10.4314/jasem.v25i2.20}

Copyright: Copyright $\odot 2021$ Mustapha et al. This is an open access article distributed under the Creative Commons Attribution License (CCL), which permits unrestricted use, distribution, and reproduction in any medium, provided the original work is properly cited.

Dates: Received: 12 December 2020; Revised: 26 January 2021; Accepted: 12 February 2021

Keyword: Weed Density, Weed Control, Yield, Pepper

Capsicum annum L. (sweet pepper) is one of the most important commercially grown vegetable crops in Nigeria. It is estimated that more than 3.38 million hectares of Capsicum are grown around the world (Peet, 2006) such as in Asia, East Africa, Central Africa, West Africa, the Caribbean, and the Philippines. The average yield of pepper (Capsicum annum L.) in West Africa is recorded as 6.7 (t/ha) FOASTAT (2012). Nigeria is the fifth in world pepper production (USDA, 2001) with over 630,000 metric tons. (Mohammad and Auwalu, 2009). Pepper is an important vegetable crop all over the world (Peet, 2006) which ranks third in the world's vegetable cycle after tomato and onion (Akinfasoye et al., 2006). Nigeria is the largest producer of the crop in Africa accounting for about $50 \%$ of African production (Erinle, 2007). However, production later declined and since 1980's export has been minimal. The impact of weeding on yield crops varies with characteristics of the crops, the weed species, weed density, environment, control methods of weeds, and duration of crop exposure to the weed (Dowson et al., 2007). Effective weed management strategies are limited for capsicum producers. Currently, weeding practices include cultural (plant density), Chemical (selective herbicides), and integrated pest management (IPM) (Weber et al., 1995, Sheikh et al., 2004). Studies on plant density for different types of pepper have shown that density and plant arrangement can influence the yield of peppers (Khasmakh - Sab. et al., 2009). Plant density is an important determinant of yield. Yield per unit area tends to increase as plant density increases to a point and tends to declines (Akintoye et al., 2009). It was also reported by Nasto et al., (2009) that increasing plant density resulted in greater yield/ha of pepper. For other crops such as radish decreasing plant density significantly reduced the total yield, but markedly enhanced root quality (El-Desuki et al., 2005A). The critical period of weed control to be carried out is usually longer in direct-seeded than in transplanted crops for example, if transplanted pepper has to be weeded from the second week until the third month after transplanting to prevent a $10 \%$ yield loss. Direct panted pepper must be weeded during the first four months after emergence to prevent the same loss (Medina, 2012). There are several post-emergence

*Corresponding Author Email: abmustaph@mautech.edu.ng 
grass killers (Usually known as 'fop' and 'dim' families) that could be used well in pepper seedbeds, as, cycloxydim for (onion, Cruciferous crops), cletodim (onion, tomatoes), fluazfob-butyl (tomato, pepper, lettuce, leek, onion) rates must be low to avoid any problem of phytotoxicity (De Linan, 2002). Weed and shortage of labor for their removal are two of the most important production constraints in smallholder farms in the northern Guinea Savanna of Nigeria (Webie et al., 1995). For instance, the small farmer spends 50 $70 \%$ of their total available farm labor on weed control, and this control is usually carried out by hand hoe weeding (Clukoye et al., 2002) although a lot of energy and resources are expected in removing weeds chemical control is easier and it saved time. Crop yields are generally very low due to untimely and ineffective weed control.Yield losses caused by weed as a result of the improper method of control by farmers has been tremendous as many farmers need to be enlightened on the danger of improper control of weed to minimize losses due to these problems caused by weed on pepper yield, farmers need to be sensitized and therefore, optimum weed control methods for optimum yield of pepper is necessary and is of interest to use effective management practices. That is why this research is designed to address the problems mentioned above with the following objective to evaluate the effect of plant population density and methods of weed control on the yield of pepper (Capsicum annum L.) in North Eastern Nigeria.

\section{MATERIALS AND METHODS}

The experiment was conducted during the 2017 wet season at Yola and Garkida. The experiment in Yola was located at the Teaching and Research Farm of the Department of Crop Production and Horticulture, Moddibo Adama University of Technology, Yola. Yola is located in the Northern Guinea savanna of Nigeria between Latitude of $9^{0} 10^{\prime} \mathrm{N}$ and Longitude $11^{\circ} 14^{\prime} \mathrm{E}$, at an altitude of $158.5 \mathrm{~m}$ above sea level (Kowal and Knabe, 1997). The annual rainfall ranges from $700-1000 \mathrm{~mm}$, and the temperature ranges from $15.2-39^{\circ} \mathrm{C}$ (Adebayo and Tukur, 1999). The experiment was sited at Garkida, Gombi Local Government Area, which lies between Latitude $10^{\circ} 9^{\prime}$ $44^{\prime \prime} \mathrm{N}$ and Longitude $12^{\circ} 44^{\prime} 24^{\prime \prime} \mathrm{E}$ also in the Northern Guinea Savanna Zone of Nigeria (Faul Michelle, 2004). The climate in the region consists rainy season (May to October) and dry season (November to April), the mean annual rainfall is about ' $850-1000 \mathrm{~mm}$, mostly distributed between May and October. Mean daily temperatures range from $20-30^{\circ}$ C. The improved hybrid seed of pepper (Capsicum annum L.) variety California wonder, and the following herbicide pendimethalin $1 \mathrm{~kg}$ a./ha, Haloxyfop -R - methyl ester $108 \mathrm{~kg} \quad$ a.1/ha, and pyrithiobac sodium $62.5 \mathrm{~kg}$ a.1/ha were obtained at Yelwa Agrochemical and Allied product shop A199 Jimeta modern market Yola Adamawa State.

The experimental design used in the research was a split-plot design with two factors, spacing and methods of weed control. Spacing was allocated to the main plot, while the method of weed control was assigned to the sub-plots. The treatment SP1 $(25 \mathrm{~cm} x$ $30 \mathrm{~cm}) 42$ plants, SP2 $(35 \times 40 \mathrm{~cm}) 30$ plants, and SP3 $(45 \times 50 \mathrm{~cm}) 16$ plants followed by the herbicide treatment which consists of HBO (which is no herbicide only hand hoe weeding), HB1 (pyrithiobac sodium $62.5 \mathrm{~kg}$ a. $1 / \mathrm{ha}$ ), HB2 (pendimethalin $1 \mathrm{~kg}$ a. $1 / \mathrm{ha}$ + pyrithiobac sodium $62.5 \mathrm{~kg}$ a.1/ha), HB3 (haloxyfop $-\mathrm{R}$ - methylester $108 \mathrm{~kg}$ a./ha followed + hand weeding only) were applied at 2, 4, and 6 weeks after transplanting. The experiment was having four (4) treatments, replicated three (3) times in plot size of $2 \mathrm{~m}$ x $2 \mathrm{~m}\left(4 \mathrm{~m}^{2}\right)$ plots, a total of 36 plots in each experimental site. A partway of $0.5 \mathrm{~m}$ was maintained between plots and $1 \mathrm{~m}$ in between replications giving a total area of the layout $23 \times 9.5=218.5 \mathrm{~m}^{2}$.

The land was cleared, beds were prepared manually with the use of hoe by following under the experimental design. The nursery bed was prepared with a good proportion of soil with a ratio 3:2:1(topsoil, compost, and fine sand) mixed in other to raise the pepper seedling three (3 weeks) before transplanting them to the experimental plots. Thinning was done after the emergence of seedling when 2-3 leaves were produced, seedlings were transplanted to the main field. After transplanting one vigorous plant is maintained per hole. Fertilizer (NPK 15:15:15) were applied at the following intervals of 3,6 and 9 weeks after transplanting. Herbicides which consist of the treatment in the sub-plots were applied as pre-plant to control weed in the experimental plot with the help of a knapsack sprayer. Other management practices like pest and disease control were applied uniformly as required.

Data were collected on the following parameters: Weed density, fruit yield per plot, and fruit yield per ha. The data obtained were subjected to the analysis of variance (ANOVA) based on split-plot design and the mean was separated using the Least Significance Difference (LSD).

\section{RESULTS AND DISCUSSION}

The combined effect of location and treatments on weed density of pepper at 2, 4, 6, and 8WAT in Yola and Garkida in 2017 wet season: The effect of the 
combined analysis indicated that there was no significant difference $(\mathrm{P} \leq 0.05)$ between locations on weed density of pepper at 2WAT. But there was a significant difference $(\mathrm{P} \leq 0.05)$ between location on weed density of pepper at 4 and 6WAT. At 4WAT Garkida recorded a weed density of 13.90, while Yola recorded a weed density of 11.39. That indicates Garkida recorded higher weed density than Yola. Similarly, at 6WAT Garkida recorded the highest weed density of 26.1, while Yola recorded the lowest density of 24.2. The effect of combined analysis of location and treatments on weed density of pepper are presented in Table 1. There was a highly significant difference $(\mathrm{P} \leq 0.001)$ between spacing on weed density of pepper at 2 WAT. Spacing, $25 \times 30 \mathrm{~cm}$ recorded the highest weed density of 13.82 , while spacing, $45 \times 50$ recorded the lowest weed density of 12.04 . On the other hand, there was no significant difference $(\mathrm{P} \leq 0.05)$ between spacing on weed density of pepper at 4 and $6 \mathrm{WAT}$. But at $8 \mathrm{WAT}$ there was a significant difference at $\mathrm{P} \leq 0.05,25 \times 30 \mathrm{~cm}$ recorded the highest weed density of 50.80 while $35 \times 40 \mathrm{~cm}$ recorded the lowest weed density of 30.50 . Concerning herbicide, there was a significant difference $(\mathrm{P} \leq 0.05)$ between herbicide on weed density of pepper at 2 and 4WAT. At 2WAT herbicide, haloxyfop + hand weeding recorded the highest weed density of 14.86 , while No herbicide gave the lowest weed density of 12.01.

Table 1: Combined mean effect of location and treatments on weed density of Pepper at 2, 4, 6, and 8WAT in Yola and Garkida locations in

\begin{tabular}{|c|c|c|c|c|}
\hline Treatments & 2WAT & 4WAT & 6WAT & 8WAT \\
\hline \multicolumn{5}{|l|}{ Location } \\
\hline Yola & 12.69 & 11.39 & 24.2 & 30.1 \\
\hline Garkida & 13.92 & 13.90 & 26.1 & 31.8 \\
\hline $\mathrm{P} \leq \mathrm{f}$ & 0.062 & 0.023 & 0.019 & 0.101 \\
\hline LSD & 1.376 & 1.654 & 1.14 & 2.49 \\
\hline \multicolumn{5}{|l|}{ Spacing } \\
\hline $25 \times 30 \mathrm{~cm}$ & 13.06 & 12.85 & 23.30 & 50.80 \\
\hline $35 \times 40 \mathrm{~cm}$ & 13.82 & 12.65 & 26.50 & 30.50 \\
\hline $45 \times 50 \mathrm{~cm}$ & 12.04 & 12.44 & 25.60 & 31.60 \\
\hline $\mathrm{P} \leq \mathrm{f}$ & 0.007 & 0.856 & 0.053 & 0.035 \\
\hline$\overline{\mathrm{LSD}}$ & 1.469 & 1.672 & 3.50 & 1.970 \\
\hline \multicolumn{5}{|l|}{$\begin{array}{l}\text { Methods of weed } \\
\text { control }\end{array}$} \\
\hline No Herbicide & 12.01 & 12.94 & 21.60 & 32.50 \\
\hline Pyrithiobac Sodium & 12.37 & 12.05 & 25.20 & 28.80 \\
\hline $\begin{array}{l}\text { Pendimethalin + } \\
\text { pyrithiobac sodium }\end{array}$ & 13.97 & 14.16 & 25.90 & 33.70 \\
\hline $\begin{array}{l}\text { Haloxyfop + hand } \\
\text { weeding }\end{array}$ & 14.86 & 11.43 & 27.80 & 28.70 \\
\hline$P \leq f$ & 0.040 & 0.015 & 0.299 & 0.226 \\
\hline LSD & 2.198 & 1.696 & 6.660 & 5.980 \\
\hline \multicolumn{5}{|l|}{ Interaction } \\
\hline $\mathrm{L} \times \mathrm{S}$ & $*$ & NS & NS & NS \\
\hline $\mathrm{L} \times \mathrm{H}$ & NS & NS & NS & NS \\
\hline $\mathrm{S} \times \mathrm{H}$ & NS & NS & NS & NS \\
\hline $\mathrm{L} \times \mathrm{S} \times \mathrm{H}$ & NS & NS & $\mathrm{NS}$ & NS \\
\hline
\end{tabular}

At 4WAT pendimethalin + pyrithiobac sodium recorded the highest weed density of 14.16 , while herbicide, Haloxyfop + hand weeding recorded the lowest weed density of 11.43 . On the other hand, there was no significant difference $(\mathrm{P} \leq 0.05)$ between herbicide on weed density of pepper at 6 and 8WAT respectively. In Garkida Table 2 location the interaction on weed density of pepper and herbicide were significant $(\mathrm{P} \leq 0.05)$. The interaction between spacing and herbicide on weed density of pepper at 4 WAT is presented in Table 16 . It is indicated that spacing, $25 \times 30 \mathrm{~cm}$ interacted with herbicide, pendimethalin + pyrithiobac sodium to record the highest weed herbicide, Haloxyfop and hand weeding gave the lowest weed density of 10.25

*=Significant, NS= Non-significant, LxS= Location by Spacing, LxH= Location by Herbicide , WAT- Weeks after transplanting

$\mathrm{SxH}=$ Spacing by herbicides, $\mathrm{LxSxH}=$ Location by spacing by Herbicide

Combined effects of location and treatments on the number of fruits/plots of pepper in Yola and Garkida location in 2017 wet season: The effects of combined analysis of location and treatments on the number of fruit/plots of pepper are presented in Table 3. The effects of the combined analysis indicated that there was a significant difference $(\mathrm{P} \leq 0.05)$ between locations on the number of fruit/plots of pepper. Garkida location recorded the highest number of fruit/plot of 63.6 while Yola location recorded the lowest number of fruit/plot of 48.1. When it comes to spacing, there was no significant difference $(\mathrm{P} \leq 0.05)$ between spacing on the number of fruit/plot of pepper.

Table 2: Interaction between spacing and methods of weed control on weed density of pepper in Garkida location at 4WAT. 


\begin{tabular}{llcll}
\hline & $\begin{array}{l}\text { No } \\
\text { Herbicide }\end{array}$ & $\begin{array}{l}\text { Pyrithiobac } \\
\text { Sodium }\end{array}$ & $\begin{array}{l}\text { Pendimethalin } \\
\text { +Pyrithiobac Sodium }\end{array}$ & $\begin{array}{l}\text { Haloxyfop and } \\
\text { hand weeding }\end{array}$ \\
\hline Spacing & & & & \\
$25 \times 30 \mathrm{~cm}$ & 17.41 & 10.99 & 18.49 & 12.98 \\
$35 \times 40 \mathrm{~cm}$ & 13.68 & 14.29 & 15.53 & 12.06 \\
$45 \times 50 \mathrm{~cm}$ & 14.91 & 12.41 & 13.80 & 10.25 \\
P $\leq \mathrm{f}$ & 0.047 & 0.047 & 0.047 & 0.047 \\
LSD & 4.547 & 4.547 & 4.547 & 4.547 \\
\hline
\end{tabular}

Table 3: Combined mean effect of location and treatment on the number of fruit/plot in Yola and Garkida location in 2017 wet season.

\begin{tabular}{ll}
\hline Treatments & \\
\hline Location & \\
Yola & 48.1 \\
Garkida & 63.6 \\
P $\leq \mathrm{f}$ & 0.036 \\
LSD & 0.09 \\
Spacing & \\
$25 \times 30 \mathrm{~cm}$ & 61.2 \\
$35 \times 40 \mathrm{~cm}$ & 54.3 \\
$45 x 50 \mathrm{~cm}$ & 52.0 \\
P<f & 0.042 \\
LSD & 2.39 \\
Method of weed control & \\
No herbicide & 64.9 \\
Pyrithiobac Sodium & 68.0 \\
Pendimethalin + Pyrithiobac Sodium & 49.7 \\
Haloxyfop + hand weeding & 40.7 \\
P $\leq \mathrm{f}$ & 0.045 \\
LSD & 23.36 \\
Interaction & \\
L x S & $\mathrm{NS}$ \\
L x H & $\mathrm{NS}$ \\
S x H & $*$ \\
L x S x H & $\mathrm{NS}$ \\
\hline Location by Spaing, LxH & \\
\hline
\end{tabular}

*=Significant, NS= Non-significant, LxS = Location by Spacing, LxH= Location by Herbicide, WAT - Weeks after transplanting, SxH= Spacing by herbicides, LxSxH= Location by spacing by Herbicide

Table 4: Interaction between location and method of weed control on number of fruits/plot of pepper in Yola and Garkida locations in 2017 wet season.

\begin{tabular}{lllll}
\hline & $\begin{array}{l}\text { No } \\
\text { Herbicide }\end{array}$ & $\begin{array}{l}\text { Pyrithiobac } \\
\text { Sodium }\end{array}$ & $\begin{array}{l}\text { Pendimethalin } \\
\text { Pyrithiobac Sodium }\end{array}$ & $\begin{array}{l}\text { Haloxyfop and } \\
\text { hand weeding }\end{array}$ \\
\hline Locations & & & & \\
Garkida & 71.3 & 288 & 271 & 233 \\
Yola & 58.4 & 224 & 128 & 289 \\
P $\leq$ f & 0.013 & 0.013 & 0.013 & 0.013 \\
LSD & 7.253 & 7.253 & 7.253 & 7.253 \\
\hline
\end{tabular}

Table 5: combined mean effect of location and treatment on yield/hectare $(\mathrm{kg})$ in Yola and Garkida location in 2017 wet season

\begin{tabular}{ll}
\hline Treatments & \\
\hline Location & 4456 \\
Yola & $4 J J$ \\
Uaı & 0.893 \\
$\mathrm{P} \leq \mathrm{f}$ & 2205.8 \\
LSD & \\
Spacing & 5632 \\
$25 \times 30 \mathrm{~cm}$ & 4640 \\
$35 \times 40 \mathrm{~cm}$ & 3212 \\
$45 \times 50 \mathrm{~cm}$ & 0.271 \\
$\mathrm{P}<\mathrm{f}$ & 3192.4 \\
LSD & \\
Methods of weed control & 4373 \\
No herbicide & 3749 \\
Pyrithiobac Sodium & 4772 \\
Pendimethalin + Pyrithiobac Sodium & 5085 \\
Haloxyfop + hand weeding & 0.465 \\
P $\leq \mathrm{f}$ & 1771.5 \\
LSD & \\
Interaction & \\
\hline
\end{tabular}

MUSTAPHA, AB; FELIX, T; TASHIWA, MC; GWORGWOR, NA 


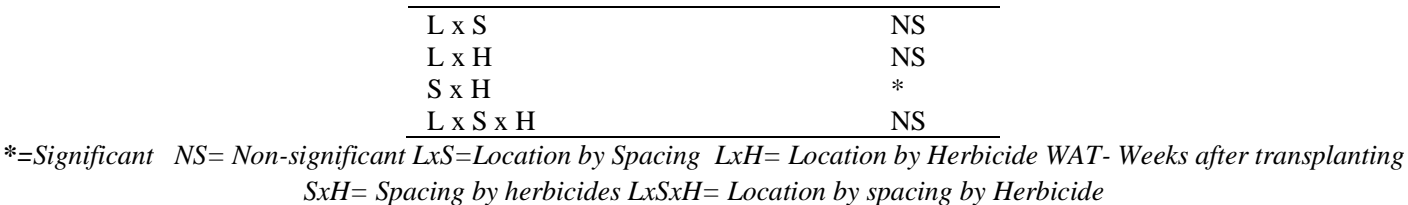

SxH= Spacing by herbicides LxSxH=Location by spacing by Herbicide

Table 6: Combined Interaction Between Spacing and method of weed control on Yield/Hectare (kg) of Pepper in Yola and Garkida Locations in 2017 Wet Season.

\begin{tabular}{lllll}
\hline & $\begin{array}{l}\text { No } \\
\text { Herbicide }\end{array}$ & $\begin{array}{l}\text { Pyrithiobac } \\
\text { Sodium }\end{array}$ & $\begin{array}{l}\text { Pendimethalin } \\
\text { Pyrithiobac Sodium }\end{array}$ & $\begin{array}{l}\text { Haloxyfop and } \\
\text { hand weeding }\end{array}$ \\
\hline Spacing & & & & \\
$25 \times 30 \mathrm{~cm}$ & 5250 & 4261 & 6755 & 6.93 \\
$35 \times 40 \mathrm{~cm}$ & 4279 & 4458 & 4358 & 5466 \\
$45 \times 50 \mathrm{~cm}$ & 3591 & 2526 & 3203 & 3528 \\
P $\leq \mathrm{f}$ & 0.049 & 0.049 & 0.049 & 0.049 \\
LSD & 8.274 & 8.274 & 8.274 & 8.274 \\
\hline
\end{tabular}

There was a significant difference $(\mathrm{P} \leq 0.05)$ between herbicide on the number of fruit/plot of pepper, herbicide pyrithiobac sodium recorded the highest number of fruit/plot of $68.0 \mathrm{~cm}$ while haloxyfop + hand weeding gave the lowest number of fruit/plot of 40.7 . The combined analysis indicated that there was interaction $(\mathrm{P} \leq 0.05)$ between location and herbicide on the number of fruit/plot of pepper. The interaction between location and herbicide are presented in Table 4. It is indicated that Garkida location interacted with herbicide pendimethalin + pyrithiobac sodium to give the highest number of fruit/plot of 72.4. while Yola location interacted with haloxyfop + hand weeding gave the lowest number of fruit/plot of 31.2.

Combined effects of location and treatments on yield/hectare of pepper in Yola and Garkida locations in 2017 wet season: The effects of combined analysis of location and treatments on yield/hectare of pepper are presented in Table 5. The effects of the combined analysis indicated that there was no significant difference $(\mathrm{P} \leq 0.05)$ between location, spacing, and herbicide on yield/hectare of pepper. The combined analysis indicated that there was interaction $(\mathrm{P} \leq 0.05)$ between spacing and herbicide on yield/hectare of pepper. The interaction between spacing and herbicide are presented in table 6 . It is indicated that spacing $25 \times 30 \mathrm{~cm}$ interacted with pendimethalin + pyrithiobac sodium recorded the highest yield per hectare with $6755 \mathrm{~kg}$ while spacing $45 \times 50 \mathrm{~cm}$ interacted with pyrithiobac sodium recorded the least yield per hectare with $2526 \mathrm{~kg}$. Effect of Plant Population Density and Methods of Weed Control on Weed Parameters: Weed Density: The weed parameters were measured on weed density $/ \mathrm{m}^{2}$. The result of the experiment on combined mean effect showed that the weed control treatment significantly affects weed density on spacing at 2 and 8WAT. At 2WAT high weed population of 13.82 weed, density $/ \mathrm{m}^{2}$ were recorded in spacing $35 \times 40 \mathrm{~cm}$ while lower weed population of 12.04 weed density $/ \mathrm{m}^{2}$ were recorded in spacing $45 \times 50 \mathrm{~cm}$. While at $8 \mathrm{WAT}$ high weed population of 31.60 weed density $/ \mathrm{m}^{2}$ was recorded in $45 \times 50 \mathrm{~cm}$ while a lower weed population of 30.50 weed density $/ \mathrm{m}^{2}$ was recorded in spacing $35 \times 40 \mathrm{~cm}$. The reason for the low weed density might be attributed to wide spacing in collaboration with herbicide application particularly pendimethalin. The result of this study is in line with the study of Hingston et al., (2006). Who reported pendimethalin as most effective and gave the best result when combined with good spacing, and when applied as pre-emergence it controls common broadleaves and grassy weeds in pepper, concerning herbicides the weed control treatments significantly affect weed density $/ \mathrm{m}^{2}$ at 2 and 4WAT respectively. At 2WAT higher weed population of 13.97 weed, density $/ \mathrm{m}^{2}$ were recorded from pendimethalin + pyrithiobac sodium while a lower weed population of 12.01 weed density $/ \mathrm{m}^{2}$ were recorded from no herbicide. The result of this study is in line with those reported by Monks et al., (2009), who concluded that proper spacing and herbicides provided satisfactory weed control. Concerning location, the weed control treatments significantly affect weed density at 4 and 6WAT respectively. At 4WAT Garkida location recorded the highest weed population of 13.90 weed density $/ \mathrm{m}^{2}$ while a lower weed population of 11.39 weed density $/ \mathrm{m}^{2}$ was recorded in the Yola location. At 6WAT Garkida location recorded the highest weed population of 24.2 weed density $/ \mathrm{m}^{2}$. It also indicates that the inherent weed population is higher than that of Yola. The result of the experiment agrees with the findings of Singh et al., (2014), who reported that sometimes weed management by herbicides do differ from location to location. Effects of Plant Population Density and Methods of Weed Control on Yield Parameters: The yield parameters are the number of fruits/plot of pepper, yield/plot, and yield/hectare. The result showed that in Yola location there was significant effect among spacing, spacing $25 \times 30 \mathrm{~cm}$ recorded the highest number of fruit/plot of 54.8 while $45 \times 50 \mathrm{~cm}$ gave the lowest number of fruit/plot of 42.8 with 
regards to the herbicide, there was no significant effect among herbicide in Yola location. The results of the study agree with Gene (2002) and Jovicich and Canttiffe (2003) who reported similar findings that there is an increasing number of fruits with wider spacing. In Garkida locations there was a significant effect among spacing, spacing $25 \times 30$ cmrecorded the highest number of fruit/plot of 67.6 while $45 \times 50 \mathrm{~cm}$ recorded the lowest number of fruit/plot of 61.2. A similar result was obtained by Narasalgi(2012) who reported that appropriate spacing influences growth and the higher number of fruit in pepper concerning herbicide there was highly significant effect among herbicide. Herbicide pyrithiobac sodium recorded the highest number of fruit/plot of 72.4 while haloxyfop + hand weeding recorded the lowest number of fruit/plot of 50.1. The result of the study agrees with the findings of Singh et al., (2010) who reported that pyrithiolobac sodium and pendimethalin at $1.0 \mathrm{~kg} \mathrm{ha} \mathrm{h}^{-1}$ controlled weed effectively in pepper and also increase the number of fruits of pepper. When it comes to yield/hectare in the Yola location, there was a significant difference in yield/hectare of pepper on spacing. Spacing $25 \times 30 \mathrm{~cm}$ recorded the highest yield/hectare with $5556 \mathrm{~kg}$ while $45 \times 50 \mathrm{~cm}$ gave the lowest yield/hectare with $3638 \mathrm{~kg}$. About herbicide, there was no significant effect among herbicides in the Yola location. The result of this experiment is in agreement with the findings of Ravanappa et al., (2012) who also obtain the highest yield with a plant density of $35 \times 50 \mathrm{~cm}$. In the Garkida location, there was a significant difference among spacing on yield/hectare of pepper. Spacing $25 \times 30 \mathrm{~cm}$ recorded the highest yield/hectare with $5707 \mathrm{~kg}$ while $45 \times 50 \mathrm{~cm}$ gave the lowest yield/hectare of $2787 \mathrm{~kg}$. The result of the experiment agrees with the findings of Machanda et al., (2008), Ramachandran and Subbiah (2011) who also obtain the yield/hectare of $(5906 \mathrm{~kg})$ from $25 \times 30$ $\mathrm{cm}$ spacing. Concerning herbicide, there was a significant difference among herbicides on yield/hectare of pepper. Herbicide pendimethalin + pyrithiobac sodium recorded the highest yield/hectare with $5629 \mathrm{~kg}$ while no herbicide gave the lowest yield/hectare with $3848 \mathrm{~kg}$. The results of the experiments agree with the findings of Joshi et al., (2017). He reported that application of alachlor 3.0 $\mathrm{kg} / \mathrm{ha}$ at $1.25 \mathrm{~kg}$ a.i/ha or pendimethalin at $0.75 \mathrm{~kg}$ a.i/ha as pre-emergence suppressed weed significantly and also recorded a higher yield of pepper.
Conclusion: The result of the experiment indicated Garkida location recorded the highest yield/hectare while the Yola location recorded the lowest yield/hectare. The result of this study revealed that pepper gave the highest yield/hectare at spacing $25 \mathrm{~cm}$ $X 30 \mathrm{~cm} 42$ plants/ha and herbicide haloxyfop followed by hand weeding only also recorded the highest yield/hectare. This result can conclusively say that pepper yield depends on the proper spacing and proper use of herbicide which will automatically suppress weed and increase the yield of pepper significantly.

\section{REFERENCE}

Akinfasoye, L.; D. J. Nmyan; R. M Tairu, (2006). Effect of Harvesting on the Duration, Yield, and Quality of Pepper. International Proceeding of $24^{\text {th }}$ Conference of Horticultural Society of Nigeria 17-22

Akintoye, H. A.; A. A. Kintonmo; A. A. Adekunle (2009). Yield and Fruit Quality of Watermelon in Response to Plant Population- International Journal of Sustainable Crop Production. 2:35-39.

De Linan, C. (2002). Vandemecum De Productos Fitosanitariosy Nutricionales. $18^{a} \quad E d$. Agroteenicas S.L Madrid. Pp.196-275.

El-Desuki M.; S. R Salman; M. A. El-Nemr; A. M. R Abdel-Magwood (2005A). Effect of Plant Density and Nitrogen Application on the Growth Yield and Quality of Radish (RaphanusSativus L.) Journal of Agronomy, 225-229.

FAOTAT (2012). Food and Agricultural Organization of United Nations Statistical Database

Gene, M., (2002) influence of plant population on transplanted processing tomatoes in lower Sacramento valley. Journal of Horticultural, science 613;107-109

Hingston, E. M.; K. K. Mahmood; T. Mehmood; Mohammed Shakeel (2006). Effect of herbicides on weed control and seedling in chili nursery. Current Res., 24:220-221.

Joshi, M.; A. S. Kumaraswamy; M. Rudraradhya; N. Krishnamurthy (2007). Effect of herbicides on weed control and seedling in chili nursery. Current Res., 24:220-221.

Jovicich, E.; D. L. Cantliffe, (2003). Reduced fertigation of soilless greenhouse peppers improves fruit yield and quality. Journal of horticultural science. 609:193-199 
Khasmakhi-Sabet, A. S.; J. M. Sedaghathoor; A. Olfati, (2009). Effect of Plant Density on Bell Pepper Yield and Quality. International Journal of Vegetable Science 15:264-271.

Manchanda, A. K.; S. Bhopal; B. Singh (2012). Effect of plant density on growth and fruit yield of bell pepper (Capsicum annum L.) Indian Journal of Agronomy (1888) 33:445-447

Medina, A. (2012). Studio de La Flora Arvense Competencia en Los Cultivos de Transplante Sienbra Directade Pimiento (Capsicum Annum L.) Pp 209 Esculenta de Ingenieria Agraria University de Lerida, Spain. (PhD. Thesis)

Monks C.D; D.W Monks; T. Bastine; A. Selders; S. Poland; E. Rayburn (2009). Soil temperature, soil moisture, weed control on tomato (Lycopersicon esculentum) response to mulching. Weed tech., 11 (3): $561-566$

Muhamman, M. A; B. M. Auwalu (2009). Seedling Performance of Sweet Pepper (Capsicum Annum L.) as Influenced by Growth Media and Fertilizer Sources in Northern Guinea Savanna Zone of Nigeria. Journal of Tropical Agriculture 6:10112.

Peet, M. (2006). Sustainable Practice for Vegetable Production in the South, North Carolina State University, USA.

Ravanappa, J.; B. H. Andrew (2012). The domesticated Capsicums. University Texas Press, Austin. (1984) P.321.
Sheikh, M. A; A. Saleem; N. A. Malik; M. A. Shahzad (2004). Assessment of Weed Complex in Spring Potato Fields of Mix-Cropping System under Irrigated Conditions of Faisalabad District, Park. Journal of Weed Science Research 10(1-2): 6372 .

Singh, E. C.; Ajaykumar, A. J. (2014). Chemical weed control on transplanted rainfed tomato (Lycopersicon esculentum mill) in the forestsavanna transition zone of southwestern India. Agric and environ., 2(2):141-150.

Singh, G. P.; K. K Thakral; M. L. Pandita (2010). Efficacy of various herbicides and hand weeding for weed control and fruit yield in chilies (capsicum annum L.) Abstracts of pepper, annual conference. Indian society of weed science hiser.

Weber, K. Elemo; S. T. O. Lagoke (1995). Weed Communities in Intensified Cereal-Based Cropping Systems of the Northern Guinea Savanna. Weed Research 35:167-178.

USDA (2001). Economic research services/USDA Agriculture outlook, April (2001) united states development for Agriculture. 